\title{
The Impact of External and Internal Factors on the Dairy Farmer's Household Economics
}

\author{
J. Atmakusuma ${ }^{\mathrm{a}, *}$, B. M. Sinaga ${ }^{\mathrm{b}}$, N. Kusnadi ${ }^{\mathrm{a}}$, \& I. K. Kariyasa ${ }^{\mathrm{c}}$ \\ ${ }^{a}$ Department of Agribusiness, Faculty of Economics and Management, IPB University (Bogor Agricultural University) \\ bDepartment of Resource and Environmental Economic, Faculty of Economics and Management, \\ IPB University (Bogor Agricultural University) \\ Jalan Kamper Kampus IPB Darmaga Bogor 16680, Indonesia \\ 'Indonesian Center for Agricultural Socio Economic and Policy Studies \\ Jalan Tentara Pelajar No. 3B Cimanggu Bogor, Indonesia \\ *Corresponding author:juniaratmakusuma@gmail.com \\ (Received 23-01-2019; Revised 08-04-2019; Accepted 03-05-2019)
}

\begin{abstract}
Domestic milk production is currently only able to meet $20 \%$ of the total domestic demand of milk, but this opportunity has not been responded well by dairy farmers. The objectives of this study were: (1) to analyze the performance of dairy farmers and (2) to analyze the impact of external factors (concentrate feed and milk prices) and internal factor (marginal productivity of concentrate feed) on production, income, and household welfare of dairy farmers. The number of sample households was 97 cooperative-member farmers and 46 cooperative-nonmember farmers in Lembang, West Java. The analytical method used included descriptive analysis and household economic models in the form of simultaneous equations. The results of the study showed that the scale of small-scale business with the percentage of lactating cattle and dairy farmers' productivity was still low. When the price of concentrate feed rises, the impact of the policy of increasing milk prices is greater than the increase in the marginal productivity of concentrate feed on increasing business income and household welfare of dairy farmers.
\end{abstract}

Keywords: production inputs; simultaneous equation models; well-being of the dairy farmers

\section{INTRODUCTION}

About $90 \%$ of dairy farmers in Indonesia are small farmers with around one to five cows ( Quen et al., 2014; Kementan, 2016; Dalewikow et al., 2016). The scale of business is difficult to increase because the percentage of lactating cows achieved is below $60 \%$ (Asmara et al., 2017; Morey, 2011; Sirajuddin et al., 2012) so that milk productivity is below $10 \mathrm{~L} / \mathrm{cow} /$ day, and consequently this condition is inefficient and not profitable (Morey, 2011; Sirajuddin et al., 2012). The ability of domestic production is only able to meet about $20 \%$ of domestic needs (Nugroho, 2012)

Farmer households act as producers with the aim of maximizing profits and as rational consumers maximizing satisfaction (Derosari et al., 2014). The decision on household consumption of farmers can affect the business of dairy cows so that the business productivity of dairy cows decreases. Farmers will sell cows without considering the contributions of cows to finance requirements of the household so that it affects the percentage of lactating cattle and milk productivity (Quen et al., 2014).

Most farmers sell milk production to the cooperatives and distributed to the Dairy Processing Industry/
IPS. Often farmers propose an increase in milk prices because the income of their businesses is insufficient to meet their daily needs, but their proposals are slowly responded by the cooperative managers because the price of milk is determined by the agreement between the cooperatives and IPS (Kumar et al., 2015). Cooperatives as providers determine the price of concentrate feed so that if there is an increase in the price of concentrate feed the cost of feed will increase (Resty et al., 2017). Increasing the cost of livestock business has resulted in the decreased farmer income (Septiani et al., 2017). Farmers reduce the use of concentrates when they are underfunded so that milk production decreases, resulting in the decreased income (Widiasti et al., 2010). Farmers who are not members of cooperatives sell milk through milk companies, and they buy concentrate feed through feed traders and behave in the same way as the cooperative-member farmers to decide the business activities (Resty et al., 2017).

Based on the background and problems of dairy cattle business activities and farmer household behavior, it becomes important to be analyzed from the household-economic perspective. The scope and analysis tools use descriptive analysis, and the household economic model of dairy cattle farmers because the households of 
dairy farmers have specificity in integrating production, consumption, and family labor allocation decisions. The objectives of this study are (1) to analyze the performance of dairy farmers, and (2) to analyze the impact of external factors (concentrate feed and milk prices) and internal factor (marginal productivity of concentrate feed) on production, income, and household well-being of dairy farmers.

\section{METHODS}

The study was conducted in May to August 2016 in Lembang District, West Bandung Regency, West Java Province. Purposive location selection was based on the consideration that Lembang is one of the main cow milk production centers in Indonesia. The sample farmer household was determined by a simple random technique of 97 cooperative-member farmers, and as many as 46 cooperative-nonmember farmers were determined by purposive sampling method. Primary data sources were cross section data for one year. The collected data were analyzed using descriptive analysis and household economic model of dairy farmers.

Descriptive analysis was used to describe the characteristics of dairy farmers, including the demographics of farmers and family members, as well as the business characteristics of dairy cows. The household economic model of dairy farmers built in the form of a simultaneous equation system consisting of 9 equations, namely 4 behavioral/structural equations, and 5 identity equations and estimated using the two stages least squares/2SLS method (Sitepu \& Sinaga, 2018). Shock was done in 3 scenarios, namely the increasing in milk prices concentrate feed price, and the marginal productivity of feed concentrates (Sinaga, 2011).

The equations of household economic model of dairy farmers are as follows:

\section{The block of dairy cow input}

The amount of concentrate feed usage

$\mathrm{QPK}=\mathrm{e}_{0}+\mathrm{e}_{1} \mathrm{HPKHSS}+\mathrm{e}_{2} \mathrm{NLPK}+\mathrm{e}_{3} \mathrm{PDRT}+\mathrm{e}_{4} \mathrm{NK}+$

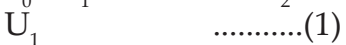

Hypothesis: $\mathrm{e}_{2}, \mathrm{e}_{3}>0 ; \mathrm{e}_{1}, \mathrm{e}_{4}<0$

\section{The block of dairy cow production}

The amount of milk production

QSS $=1_{0}+1_{1} \mathrm{QPK}+\mathrm{U}_{2}$

Hypothesis: $\mathrm{l}_{1}>0$

Milk productivity

YSS= QSS / QSL

3. The block of household income of farmers

Revenue from milk

$\mathrm{PNSS}=\mathrm{HSS}^{*} \mathrm{QSS}$

Household income of farmer

PDRT $=$ PDSP + PDNSP

4. The block of household expense of farmers

Food and non-food consumption expense

$\mathrm{NK}=\mathrm{NKPNG}+\mathrm{NKNPNG}$
Dairy cow business investment expense

$\mathrm{NIVSP}=\mathrm{r}_{0}+\mathrm{r}_{1} \mathrm{PDRT}+\mathrm{r}_{2} \mathrm{NK}+\mathrm{r}_{3} \mathrm{NIVSDM}+\mathrm{r}_{4} \mathrm{DUAK}+$ $\mathrm{U}_{3} \ldots \ldots \ldots . . .(7)$

Hypothesis: $r_{1}, r_{4}>0 ; r_{2}, r_{3}<0$

Education investment expense

$\mathrm{NIVPDD}=\mathrm{s}_{0}+\mathrm{s}_{1}$ PDRT $+\mathrm{s}_{2} \mathrm{NIVSP}+\mathrm{s}_{3} \mathrm{DUAK}+\mathrm{U}_{4}$

Farmer household expense

$\mathrm{PGRT}=\mathrm{NK}+\mathrm{NIV}$

Where: QPK is the amount of concentrates feed $(\mathrm{Kg} /$ year), HPKHSS is concentrate feed price/milk prices, QSS is the amount of milk production (L/year), QSL is the number of lactating cow (cow), YSS is milk productivity (L/cow), PNSS is milk revenue (000 IDR/year), PDNSP is business income other than dairy cows (IDR/ year), PDRT is household income (000 IDR/year)), PDSP is income from dairy cow business (000 IDR/year), NKPNG is food consumption (000 IDR/year), NKNPNG is non food consumption (000 IDR/year), NK is food and non food consumption (000 IDR/year), NIVSP is dairy cow investment (000 IDR), NIVPDD is education investment (000 IDR), NIVSDM is human resource investment (000 IDR), NIV is total investment (000 IDR), PGRT is household expense (000 IDR/year), HPK is concentrate feed price (IDR/Kg), NLPK is loan value of concentrate feed (IDR/Year), HSS is milk prices (IDR/L), DUAK is business scale dummy $(0=3-5$ cows, $1=6-10$ cows $)$, and $\mathrm{U}$ is residues.

\section{RESULTS}

\section{Characteristics of Dairy Farmers Household}

The household characteristics of dairy farmers are used in analyzing the economic activities of household members. Table 1 present the household characteristics of cooperative-member and cooperative-nonmembers of dairy farmers. It can be seen that $95.5 \%$ of respondents stated that raising livestock was the main job. The average age of dairy farmers, both cooperative-members and cooperative-nonmembers were relatively the same (40.78 and 40.82 years). The formal education of cooperative-member and cooperative-nonmember farmers relatively low, i.e. 8.33 and 8.00 years schooling respectively, with experience in farming 13.39 and 11.72 years for cooperative-member farmers and cooperativenonmembers farmers, respectively.

The number of family members of cooperativemember farmers and cooperative-nonmembers farmers was the same; that was 3 people, with $30 \%$ and $35 \%$ were students and $69 \%$ and $71 \%$ helping to work in livestock businesses. Farmers of cooperative-member were given counseling and training by extension workers from the Office of Cooperatives and Animal Husbandry Ser-vices, at least once a year. Farmers who were not the members of cooperative get information from the Milk Processing Industry and Animal Husbandry Service. 


\section{Characteristics of Dairy Farmers Household Business}

Based on Table 2, the cooperative-nonmember farmer had more dairy cows than cooperative-member farmers (7.33 vs. $6.05 \mathrm{AU})$ with the same percentage of lactating cows, which was around $61 \%$. Dairy production of cooperative-member farmer was higher than cooperative-nonmember farmers ( 18.40 vs. $16.19 \mathrm{~L}$ milk/ day) and milk productivity were still low (10.55 vs 8.30 L milk/cow/day).

In dairy cows business, concentrate feed and forage were essential inputs. The cost of concentrate feed in cooperative-member and cooperative-nonmember dairy farmer were $91.70 \%$ and $90.66 \%$, respectively, of the business costs of dairy cows (Table 3). Concentrate feed were purchased from cooperatives and animal feed traders. Forage feeds in the form of field grass, elephant grass, and king grass was obtained through flaking. Farmers also used agricultural waste as forage. The volume ratio ( $\mathrm{kg}$ dry matter) for concentrates and forages was 36\%:65\% for cooperative-member farmers and 34\%:66\% for cooperative-non member farmers.

Table 4 showed that the contribution of male-family labor about $93.54 \%$ (cooperative member) and $93.59 \%$ (cooperative-nonmember) of labor force. This number indicates that male family labor plays an important role in running a dairy business while female-family labors are involved in helping to manage dairy cows with less time, which is $4.81 \%$ and $4.58 \%$ for cooperative-member

Table 1. Household characteristics of dairy farmers in Lembang, West Java, 2016

\begin{tabular}{lcc}
\hline & \multicolumn{2}{c}{$\begin{array}{c}\text { Average of dairy farmers } \\
\text { household }\end{array}$} \\
\cline { 2 - 3 } $\begin{array}{l}\text { Dairy farmers household } \\
\text { characteristics }\end{array}$ & $\begin{array}{c}\text { Cooperative } \\
\text { member } \\
(\mathrm{n}=97)\end{array}$ & $\begin{array}{c}\text { Cooperative } \\
\text { nonmember } \\
(\mathrm{n}=46)\end{array}$ \\
\hline Farmer's age (year) & 40.78 & 40.82 \\
Formal education (year) & 8.33 & 8.00 \\
$\begin{array}{l}\text { Dairy farming experience } \\
\text { (year) }\end{array}$ & 13.39 & 11.72 \\
Main job as a farmer (\%) & 95.5 & 95.00 \\
Side job as a farmer (\%) & 4.50 & 5.00 \\
$\begin{array}{l}\text { Numbers of family member } \\
\text { (person) }\end{array}$ & 3 & 3 \\
Ratio of school children (\%) & 30.00 & 35.00 \\
Ratio of family labor (\%) & 70.00 & 65.00 \\
\hline
\end{tabular}

Table 2. The number of dairy cow ownership and productivity in Lembang, West Java, 2016

\begin{tabular}{lcc}
\hline Components & $\begin{array}{c}\text { Cooperative } \\
\text { member } \\
(\mathrm{n}=97)\end{array}$ & $\begin{array}{c}\text { Cooperative } \\
\text { nonmember } \\
(\mathrm{n}=46)\end{array}$ \\
\cline { 2 - 3 } Number of dairy cows (AU) & 6.05 & Unit \\
\hline Number of lactating cow (\%) & 61.44 & 7.33 \\
Number of non-lactating cow (\%) & 38.56 & 38.47 \\
Productivity (L milk/farmer/day) & 18.40 & 16.19 \\
Productivity (L milk/cow/day) & 10.55 & 8.30 \\
\hline
\end{tabular}

and cooperative-nonmember farmers, respectively. Hired-male labor helped dairy cows business with a small portion of $1.65 \%$ and $1.82 \%$ in cooperative-members and cooperative-nonmembers farms.

\section{Dairy Farmer Household Income and Expense}

The household income of dairy farmers consists of income from dairy cow business and other businesses. The income of dairy cows derived from the sales of milk and rejected cows, subtracted by operation cost of the dairy business as shown in Table 5 .

The most significant revenue of cooperative-member and cooperative-nonmember dairy farmers originated from milk sales, i.e. $93.02 \%$ and $95.35 \%$, respectively, while the revenue from rejected cow sales was $6.98 \%$ and $4.65 \%$, respectively. The largest household income of the farmers both cooperative-members and cooperative-nonmembers was from the dairy business (99\%), while the rest was from trading and transportation services. The household income of cooperative-member and cooperative-nonmember dairy farmers was used for household expenditure and investment as could be seen in Table 6.

Food-consumption expenditures indicate the level of household food security or welfare. Foodconsumption expenditure of cooperative-member farmers $(48.48 \%)$ was smaller than nonfood-consumption expenditure $(51.52 \%)$. On the other side, the foodconsumption expenditure of cooperative-nonmember farmers $(53.52 \%)$ was higher than nonfood-consumption expenditure $(46.46 \%)$.

Table 3. The input value of dairy cow business in Lembang, West Java, 2016

\begin{tabular}{lrrrr}
\hline Input & $\begin{array}{c}\text { Cooperative member } \\
(\mathrm{n}=97)\end{array}$ & \multicolumn{2}{c}{$\begin{array}{c}\text { Cooperative } \\
\text { nonmember } \\
(\mathrm{n}=46)\end{array}$} \\
\cline { 2 - 5 } & \multicolumn{1}{c}{ IDR/year } & \multicolumn{1}{c}{$\%$} & \multicolumn{1}{c}{ IDR/year } & $\%$ \\
\hline Concentrate & $19,717,809.80$ & 91.70 & $22,716,124.08$ & 90.66 \\
feed & & & & \\
Forage feed & $1,685,325.41$ & 7.84 & $2,226,873.57$ & 8.89 \\
$\begin{array}{l}\text { Medicine and } \\
\text { vitamin }\end{array}$ & $49,721.21$ & 0.23 & $45,184.45$ & 0.18 \\
Equipment & $50,448.20$ & 0.23 & $68,374.16$ & 0.27 \\
Total & $21,503,304.62$ & 100.00 & $25,056,556.25$ & 100.00 \\
\hline
\end{tabular}

Table 4. Labor allocation for dairy cow business in Lembang, West Java, 2016

\begin{tabular}{lcccr}
\hline & \multicolumn{2}{c}{$\begin{array}{c}\text { Cooperative } \\
\text { member } \\
\text { Labor }\end{array}$} & $\begin{array}{c}\text { Cooperative } \\
\text { nonmember } \\
(\mathrm{n}=97)\end{array}$ & \multicolumn{2}{c}{$\begin{array}{c}\text { M6) } \\
\text { Man-days/ } \\
\text { year }\end{array}$} & $\%$ & $\begin{array}{c}\text { Man-days/ } \\
\text { year }\end{array}$ & $\%$ \\
\cline { 2 - 5 } & 196.14 & 93.54 & 202.22 & 93.59 \\
Male-family labor & 10.09 & 4.81 & 9.9 & 4.58 \\
$\begin{array}{l}\text { Female-family } \\
\text { labor }\end{array}$ & & & & 1.82 \\
Male-hired labor & 3.45 & 1.65 & 3.94 & 100.00 \\
$\begin{array}{l}\text { Labor for dairy } \\
\text { cow business }\end{array}$ & 209.68 & 100.00 & 216.06 & \\
\hline
\end{tabular}


Table 5. Dairy farmer household income in Lembang, West Java, 2016

\begin{tabular}{lrrrr}
\hline \multirow{2}{*}{ Source of income } & \multicolumn{2}{c}{ Cooperative member $(\mathrm{n}=97)$} & \multicolumn{2}{c}{ Cooperative nonmember $(\mathrm{n}=46)$} \\
\cline { 2 - 5 } & \multicolumn{1}{c}{ IDR } & \multicolumn{1}{c}{ IDR } & \multicolumn{1}{c}{$\%$} & 95.35 \\
\hline Milk sales & $98,421,943.07$ & 93.02 & $100,439,279.03$ & 4.65 \\
Rejected cow sales & $7,385,260.44$ & 6.98 & $4,902,551.35$ & 100.00 \\
Dairy cow business revenue & $105,807,203.51$ & 100.00 & $105,341,830.37$ & 99.89 \\
\hline Dairy cow business income & $84,303,898.89$ & 99.71 & $80,285,274.13$ & 100.00 \\
Farmer household income & $84,551,321.57$ & 100.00 & $80,372,230.65$ & \\
\hline
\end{tabular}

Table 6. Dairy farmer household expense in Lembang, West Java, 2016

\begin{tabular}{|c|c|c|c|c|}
\hline \multirow{2}{*}{ Source of expense } & \multicolumn{2}{|c|}{ Cooperative member $(n=97)$} & \multicolumn{2}{|c|}{ Cooperative nonmember $(n=46)$} \\
\hline & IDR & $\%$ & IDR & $\%$ \\
\hline Food consumption expense & $13,526,528.88$ & 48.48 & $9,479,992.49$ & 53.54 \\
\hline Non-food consumption expense & $14,373,784.73$ & 51.52 & $8,227,763.41$ & 46.46 \\
\hline Total consumption expense & $27,900,313.61$ & 100.00 & $17,707,755.90$ & 100.00 \\
\hline Dairy cow investment expense & $6,963,174.79$ & 47.73 & $4,561,221.12$ & 84.68 \\
\hline Education investment expense & $7,399,234.08$ & & $711,439.14$ & \\
\hline Health investment expense & $22,204.65$ & & $113,581.63$ & \\
\hline Human resource investment expense & $7,624,438.73$ & 52.27 & $825,020.77$ & 15.32 \\
\hline Total investment expense & $14,587,613.52$ & 100.00 & $5,386,241.89$ & 100.00 \\
\hline Total household expense & $42,487,927.13$ & & $23,093,997.79$ & \\
\hline
\end{tabular}

The cooperative-member and cooperative-nonmember dairy farmers households allocate their income up to $34.33 \%$ and $23.32 \%$, respectively, for investment. In cooperative-member farmers, investment in the dairy business $(47.73 \%)$ was smaller than investment in human resources $(52.27 \%)$, whereas in cooperativenonmember farmers, investment in the dairy business $(84.68 \%)$ was higher than investment in human resource. Expenditures for investment for household education in cooperative-member farmers were higher than in cooperative-nonmember farmers.

\section{Impact of Changes in External and Internal Factors on the Farmer Households Well-being}

Analysis of the impact of changes in external factors, i.e., increases in concentrate feed prices and milk prices. The simulation was done based on the tendency to the increased price of concentrate feed. Based on the experience of farmers, the simulation was done by increasing the price of concentrate feed by $20 \%$. At each Annual Member Meeting (RAT) of the cooperative, the member farmers proposed an increase in the price of milk, but the cooperative management responds less. This low response was caused by the fact that the price of milk was determined by the agreement between Milk Processing Industry and cooperatives while the bargaining position of cooperatives was relatively lower. The farmer expectation of an increase in the price of milk by $1,000.00 \mathrm{IDR} / \mathrm{L}$ from the price currently received, which was 4,714.12 IDR/L for cooperative-member farmers and 4,703.13 IDR/L for cooperative-nonmember farmers.

The impact simulation of changes in internal factors was conducted by increasing the productivity of concentrate feed. The dairy cow production model (equation
2) stated that there is only one variable i.e. concentrate feed (QPK), which significantly affected milk production (QPK). The marginal productivity of concentrate feed was $0.74 \mathrm{~L}$ (parameter estimation). Cooperative recommended the use of concentrate feed ratio at 1.5 (one $\mathrm{kg}$ concentrate feed produced $1.5 \mathrm{~L}$ of milk), reconfirming the increase in the productivity of concentrate feed could be done. The farmer's internal effort by increasing the marginal productivity of concentrate feed by $40 \%$ (simulation 2), had increased the marginal productivity of milk by $1.04 \mathrm{~L}$. There were other factors that influence milk productivity, namely breeding factors, environment, management, and others.

Table 7 shows the impact of the simulation combination on increasing the concentrate feed prices and milk prices (simulation 1) and the impact of a single simulation on increasing the marginal productivity of concentrate feed (simulation 2). It also shows the simulation effect of a combination on increasing concentrate feed price and marginal productivity of concentrate feed (simulation 3) on production, income, and the welfare of the dairy farmers.

\section{Impact of Increase in Feed Prices and Milk Prices}

As a result of an increase in concentrate feed (HPK) prices by $20 \%$ along with an increase in milk prices (HSS) of 20\% (Table 7 simulation 1), cooperativemember farmers reduced the use of concentrate feed (QPK) by $0.23 \%$ while nonmember farmers were able to increase the use of concentrate feed (QPK) by $2.86 \%$. The reduction of concentrate feeds caused milk production (QSS) to decrease by $0.06 \%$ for cooperative-member farmers, while for cooperative-nonmember farmers increased by $0.72 \%$ because it was still able to increase feeding. 
Table 7. The impact of increasing concentrate feed prices (HKP), milk prices (HSS), and increasing marginal productivity of concentrates feed on production, income, and well-being of dairy farmers in Lembang, West Java in 2016

\begin{tabular}{|c|c|c|c|c|c|c|c|c|c|}
\hline \multirow{3}{*}{ Block } & \multirow{3}{*}{$\begin{array}{l}\text { Exogenous } \\
\text { variable }\end{array}$} & \multirow{2}{*}{\multicolumn{2}{|c|}{ Basic value }} & \multicolumn{6}{|c|}{ Changes (\%) } \\
\hline & & & & \multicolumn{2}{|c|}{ Simulation 1} & \multicolumn{2}{|c|}{ Simulation 2} & \multicolumn{2}{|c|}{ Simulation 3} \\
\hline & & A & NA & $\mathrm{A}$ & NA & A & NA & A & NA \\
\hline \multicolumn{10}{|l|}{ USE OF INPUT } \\
\hline Amount of concentrates $(\mathrm{Kg})$ & QPK & $7,220.03$ & $7,165.64$ & -0.23 & 2.86 & 1.90 & 1.85 & -3.67 & -0.64 \\
\hline \multicolumn{10}{|l|}{ PRODUCTION } \\
\hline Amount of milk production (L) & QSS & $20,878.13$ & $20,838.09$ & -0.06 & 0.72 & 10.90 & 10.78 & 8.87 & 9.90 \\
\hline Milk productivity (L milk/cow) & YSS & $6,166.34$ & $6,523.20$ & -15.10 & -15.40 & 7.17 & 7.08 & -4.81 & -5.05 \\
\hline \multicolumn{10}{|l|}{ INCOME } \\
\hline Milk revenue (000 IDR) & PNSS & $98,421.94$ & $98,004.27$ & 19.93 & 20.87 & 10.90 & 10.78 & 8.87 & 9.90 \\
\hline Household income (000 IDR) & PDRT & $84,551.32$ & $79,288.17$ & 19.76 & 20.37 & 12.70 & 13.14 & 7.48 & 7.62 \\
\hline \multicolumn{10}{|l|}{ EXPENSE } \\
\hline $\begin{array}{l}\text { Food and non food consumption } \\
\text { (000 IDR) }\end{array}$ & NK & $27,900.31$ & $17,609.36$ & 5.47 & 8.37 & 3.51 & 5.40 & 2.07 & 3.13 \\
\hline Dairy cow investment (000 IDR) & NIVSP & $6,963.17$ & $4,468.97$ & 19.77 & 29.76 & 12.70 & 19.20 & 7.48 & 11.13 \\
\hline Education investment (000 IDR) & NIVPDD & $7,399.23$ & 691.22 & 4.25 & 43.96 & 2.73 & 28.36 & 1.61 & 16.45 \\
\hline Household expense (000 IDR) & PGRT & $42,487.93$ & $22,903.38$ & 7.58 & 13.60 & 4.86 & 8.77 & 2.87 & 5.09 \\
\hline
\end{tabular}

Notes: Simulation $1=$ The combination of an increase in concentrate feed prices (HPK) by $20 \%$ and a rise in milk prices (HSS) by $20 \% *$; Simulation $2=$ Concentrate feed marginal productivity increased milk production by $40 \% * *$; Simulation $3=$ The combination of an increase in concentrate feed prices (HPK) by $20 \%$ * and an increase in marginal productivity of concentrates feed on milk production by $40 \%$ **; $\mathrm{A}=\mathrm{Cooperative-member}$ farmer; NA= Cooperative- nonmember farmers; $(-)=$ Not available; ${ }^{*}=$ External factor; ${ }^{* *}=$ Internal factor; QPK is the amount of concentrates feed (Kg/year); QSS is the amount of milk production (L/year); YSS is milk productivity (L/cow); PNSS is milk revenue (000 IDR/year); PDRT is household income (000 IDR/year); NK is food and non food consumption (000 IDR/year); NIVSP is dairy cow investment (000 IDR); NIVPDD is education investment (000 IDR); PGRT is household expense (000 IDR/year).

Even though the price of concentrate feed and milk prices rose, the revenue from milk sales (PNSS) increased by $19.93 \%$ and $20.87 \%$, so that farmers' household income (PDRT) increased by $19.76 \%$ and $20.37 \%$ for cooperative-member and cooperative non-member farmers, respectively. The farmer welfare increased with the increased household expenditure (PGRT) by $7.58 \%$ and $13.60 \%$, respectively, for cooperativemember farmers and cooperative-nonmembers farmers. With the increased farmer welfare, it could increase food and non-food consumption by $5.47 \%$ and $8.37 \%$, respectively, in cooperative-members and cooperativenon member farmers. There was an increase in investment in dairy cow business by $19.77 \%$ and $29.76 \%$ in cooperative-member and cooperative-nonmember farmers, respectively, while the investment in education for cooperative-nonmember farmers $(43.96 \%)$ was higher than cooperative-member farmers $(4.25 \%)$.

\section{Impact of Increasing Marginal Concentrate Feed Productivity}

Table 7 (simulation 2) shows that the use of concentrate feed (QPK) in cooperative-member and cooperative-nonmember farmers increased by $1.90 \%$ and $1.85 \%$, respectively so that milk production (QSS) increased by $10.9 \%$ and $10.78 \%$ with milk productivity (YSS) increased by $7.17 \%$ and $7.08 \%$. Further revenue from milk sales (PNSS) increased by $10.90 \%$ and $10.78 \%$ so that the farmer's household income (PDRT) increased by $12.70 \%$ and $13.14 \%$, respectively, for cooperative-members and cooperative-nonmember farmers.
Household expenses (PGRT) increased by $4.86 \%$ and $8.77 \%$, respectively, for cooperative-member farmers and cooperative-nonmember farmers so that farmers' household welfare increased. There was an increase of investment in the dairy cow business (NIVSP) of cooperative-nonmember farmers (19.20\%) that was greater than in cooperative-member farmers $(12.70 \%)$, as well as the increased investment in education in cooperative-nonmember farmers $(28.36 \%)$ that was greater than in cooperative-member farmers $(2.73 \%)$.

\section{Impact of Feed Price Increase and Increased Marginal Concentrate Feed Productivity}

At the time of increasing marginal productivity of concentrate feed to marginal productivity of milk production by $40 \%$ and an increase in concentrate feed (HPK) prices by $20 \%$ as in Table 7 (simulation 3) there was a decrease in concentrate feed use (QPK) in cooperative-member farmers $(3.67 \%)$ that was greater than in cooperative-nonmembers farmers (0.64\%). This condition led to a decrease in milk productivity (YSS) by $4.81 \%$ and $5.05 \%$, but milk production (QSS) still increased by $8.87 \%$ and $9.90 \%$, respectively, for cooperative-member and cooperative-nonmember farmers.

Milk income (PNSS) still increased by $8.87 \%$ and $9.90 \%$ and the impact on farmers' household income (PDRT) increased by $7.48 \%$ and $7.62 \%$ in cooperativemember farmers and cooperative-nonmember farmers, respectively. There was an increase in the farmers welfare with the increased farmers' household expenditure 
(PGRT) which increased by $2.87 \%$ and $5.09 \%$, used for increasing food and non-food consumption (NK) of $2.07 \%$ and $3.13 \%$. Other expenditures for dairy business investment (NIVSP) in cooperative-member and cooperative-nonmember farmers were $7.48 \%$ and $11.13 \%$, while for education investment (NIVPDD) was $16.45 \%$ and $1.61 \%$ in cooperative-member farmers increased more than in cooperative-nonmember farmers.

\section{DISCUSSION}

\section{Characteristics of Dairy Farmers}

The results of the study indicate that the ages of dairy farmers, both cooperative-members and cooperative-nonmembers farmers are relatively same, i.e. in the productive age group. The opportunity for farmers to carry out formal education between cooperativemember farmers and cooperative-nonmembers farmers is also low because they focus on working to maintain dairy cows. About $95 \%$ of cooperative-members and cooperative-nonmember farmers stated that the dairy cow business was the main job and was reflected in the experience of farming that had been carried out for quite a long time. In contrast to the research of Elizaphan et al. (2016) in East Africa, the average age of farmers was higher at 51 years. Likewise, formal education is almost the same, namely 7 years but has a longer experience of raising about 18 years.

The dairy cow business is a business that involves family members such as wive, children, or other family members so that it is known as animal husbandry. Family members who are still in school are involved according to their capacities so that almost all family members are the family workforce (Wantase \& Paputungan, 2017; Ramadhan et al., 2015).

\section{Characteristics of Dairy Cow Business}

The ownership compositions of dairy cows greatly influence the success of the business. The scale of dairy cattle ownership is 6.05 and 7.33 cows per cooperativemember farmer and cooperative-nonmember farmers. This condition is the same as folk farmers in Bangladesh with an ownership scale of 1.89 and 11.10 cows (Khan et al., 2010). The composition of lactating cow for cooperative-nonmember farmers is greater (61.06\%) than for cooperative-member farmers (60.32\%). The results of this study were lower than the results of Quen et al. (2014) stated that composition lactating cow in Pangalengan was $77.19 \%$ and Ohla (2013) in India reaches $72 \%$. However, Santoso et al. (2016) reported the lower condition with the percentage of lactating cow in KUD Getasan, KUD Sumber Karya, and KUD Mekar Kabupaten Semarang were to $42.8 \%, 55.9 \%$, and $57.4 \%$, respectively. With the percentage of lactating cow that is less than $60 \%$, the dairy cow business was not efficient and profitable (Sirajuddin et al., 2012). Also, Halolo et al. (2013) and Ekowati et al. (2011) informed the profitability of dairy cows through the percentage of lactating cow more than $60 \%$ with the efficiency level of 1.2-1.4.
About $80 \%$ of the dairy farming costs are feed costs (Quen et al., 2014). In this study, the cost of concentrate feed reached $90 \%$ and forage feed costs around $7 \%$. The results of this study are similar to those reported by Asmara et al. (2017) where forage costs reaching $4.89 \%$ to $7.47 \%$ in small and large-scale dairy farmers in West and East Java.

The largest allocation of male-family labor for dairy cow business is only $5 \%$ of farmers, because they have activities outside of dairy cow business. The allocation of female workers in the family of about $4 \%$ is used to work in the dairy business. Since early morning the farmers work for milking, cleaning the cow and the cage. Furthermore, doing routine work of raising cattle until the afternoon so there is not much time to do work other than dairy cattle business. The length of time devoted to raising dairy cows is 6.92 hours per day with long periods from early morning to night. This is in accordance to the household economic theory that raising dairy cows are managed by household farmers so that they cannot be separated between production decisions and household decisions. The dairy cattle business has problems with low productivity and genetic quality of livestock, low exploitation scale, availability of concentrate feed that do not fulfill nutrition, and maintenance management still needs to be improved (Anh et al., 2013; Srairi et al., 2010).

The biggest dairy cow business income from milk sales reached $93.02 \%$ and $95.35 \%$ for cooperativemember farmers and cooperative-nonmember farmers. While the research of Santoso et al. (2016) in Semarang Regency farmers found household income of $99.71 \%$ and $99.89 \%$ in cooperative-members and cooperativenonmember farmers originating from dairy cows.

The results of studies of food and non-food expenditure from cooperative-member and cooperativenonmember farmers are the same as household/farm household expenditures in studies of Saefullah et al. (2012), Derosari et al. (2014), and Yuliandri (2015) namely food consumption expenditures of $43 \%-55 \%$ and nonfood items at $45 \%-56 \%$. Food consumption expenditures indicate the problem of food security or well-being. Based on the threshold, the level of food expenditure is $60 \%$ or with calorie adequacy of $80 \%$. For this reason, cooperative-member and cooperative-nonmember farmers have shown food expenditure in the percentage below $60 \%$. If referring to Engel's Curve that the tendency for cooperative-member farmers, the percentage of food expenditure is smaller than non-food expenditure.

\section{Impact of Increase in Concentrate Feed Prices, Milk Prices, and Increase in Marginal Productivity Concentrate Feed on Household Well-being}

The increasing of marginal productivity of concentrate feed by $40 \%$ (simulation 2) will increase the use of concentrate feed. Even though milk prices increase by $20 \%$ along with an increase in concentrate feed prices, cooperative-member farmers reduce their use. However, when the concentrate feed price increase and the increasing of the marginal productivity of concentrate 
feed are done (simulation 3), there is a decrease in the use of concentrate feed.

When there is an increase in concentrate feed prices, the impact of an increase in milk prices (simulation 1) on the increase in milk production is lower than when increasing the marginal productivity of the concentrate together with an increase in feed prices (simulation 3). The impact of the increase in milk prices despite an increase in the price of concentrate feed can increase the highest investment in dairy cows. Also, the highest increase in household expenditure is that farmers are more prosperous than when increasing the marginal productivity of feed, there is an increase in the price of concentrate feed.

To improve the household welfare of dairy farmers when the price of concentrate feed increasing, the policy of increasing milk prices needs to be implemented. To increase the marginal productivity of concentrate feed, cooperatives as providers of concentrate feed can facilitate farmer's accessibility to get good quality of concentrate feed, such as increase protein content, and dairy cows.

\section{CONCLUSION}

Cooperative-member and cooperative-nonmember farmers are in the productive age with low education, but the experience is long enough so that the dairy cow business becomes its main job. The scale of cattle ownership is still low with the percentage of lactating cattle and milk productivity are still low. In conditions of increasing concentrate feed prices, the impact of increasing milk prices is greater than the increase in marginal productivity of concentrate feed on increasing business income and household well-being of dairy farmers.

\section{CONFLICT OF INTEREST}

We certify that there is no coflict of interest with any financial, personal, or other relationships with the other people or organization related to the material discussed in the manuscript.

\section{REFERENCES}

Anh, N.H., T.H. Cuong, \& B.T.Nga. 2013. Production and marketing constraints of dairy farmers in Son La milk value chain, Vietnam. Greener Journal of Business and Management Business 3:031-037.

Asmara, A., Y.L. Purnamadewi, \& D. Lubis. 2017. The relationship analysis between service performances of milk producer cooperative with the dairy farm performance of members. Med. Pet. 40:143-150. https://doi.org/10.5398/ medpet.2017.40.2.143

Dalewikow, R.L., W. Sumekar, \& A.Setiadi. 2016. The profitability analysis of dairy cattle business on the group of dairy farmers in West Ungaran District Semarang Regency. J. Indonesian Trop. Anim. Agric. 4:216-223. https://doi. org/10.14710/jitaa.41.4.216-223

Derosari, B.B, B.M. Sinaga, N. Kusnadi, \& M.H. Sawit. 2014. The impact of credit and capital supports on economic behavior of farm households: A household economic approach. Int. J. Food Agric. Econ. 2:81-90.
Ekowati,T., D.H. Darwanto, S. Nurtini \& A. Suryantini. 2011. The Analysis of beef cattle subsystem agribusiness implementation in Central Java Province, Indonesia. J. Indonesian Trop. Anim. Agric. 36:281-289. https://doi. org/10.14710/jitaa.36.4.281-289

Elizaphan, J.O.R, I. Omondi, A.A. Karimov, \& I. Baltenweek. 2016. Dairy farm households, processor linkages and household income: the case of dairy hub linkages in East Africa. International Food and Agribusiness Management Review 19:95-108. https://doi.org/10.22434/IFAMR2014.0177

Halolo, R.D., S.I. Santoso, S. Marzuki, W. Roessali, \& A. Setadi. 2013. Profit function analysis of dairy cattle farming in Getasan and West Ungaran Districts, Semarang Regency. J. Indonesian Trop. Anim. Agric 38: 65-72. https:// doi.org/10.14710/jitaa.38.2.116-122

[Kementan. 2016]. Kementerian Pertanian 2016. Outlook Susu: Komoditas Pertanian Subsektor Peternakan. Jakarta (ID): Kementan.

Khan, A.B.M.K.I, M.A. Baset, \& S.K. Fouzder. 2010. Study on management and production system of small scale dairy farm in a selective rural area of Bangladesh. J. Sci. Foundation. 8:13-23. https://doi.org/10.3329/jsf. v8i1-2.14615

Kumar,V., K.G. Wankhede, \& H.C. Gena. 2015. Role of cooperatives in improving livehood of farmers on sustainable basis. Am. J. Educ. Res. 3:1258-1266.

Morey, P. 2011. Report for International Finance Corporation on "Indonesia Dairy Industry Development". International Finance Corporation. Morelink Asia Pasific. Vic 3629. Australia.

Nugroho, B.A. 2012. The relevance of a rules-based fresh milk price structure policy in East Java: An evidence-based assesment. International Journal of Rural Studies (IJRS). 19:1-7.

Ohla, R. 2013. Effeciency and total factor productivity growth in India dairy sector. Quarterly Journal of International Agriculture. 52:1-10

Quen, T.M.A., A.D. Lestari, \& S. Situmorang. 2014. The analysis of income and welfare level of animal husbandry cooperation's member in South Bandung (KPSBS Pangalengan). Jurnal Ilmu Ilmu Agribisnis (JIIA) 2:109-117.

Ramadhan, D.R, S. Mulatsih, \& A.A. Amin. 2015. Sustainable dairy cattle farming system: A case study of smallholders in Bogor Regency. Jurnal Agro Ekonomi 33:51-72. https://doi.org/10.21082/jae.v33n1.2015.51-72

Resty, Y., R. Baars, M. Vershurr, \& G. Duteurtre. 2017. The role of cooperative in the milk value chain in West Bandung Regency, West Java Province. Med. Pet. 40:210-2017. https://doi.org/10.5398/medpet.2017.40.3.210

Saefullah, R., S. Marzuki, \& M. Handayani. 2012. Comparation of costs and revenues of dairy farm between village unit cooperative members and non-members of village unit cooperative in Banyumas Regency. Animal Agriculture Journal 1:845-858.

Santoso S.I., H.I. Nisa, Mukson Mukson, \& M. Handayani. 2016. Profitability analysis of dairy cattle farming of village cooperative members in Semarang Regency. Jurnal Ilmu dan Teknologi Peternakan 4:139-145.

Septiani, W., Marimin, Y. Herdiyeni, \& L. Haditjaroko. 2017. Risk base milk pricing model at dairy farmers level. Med. Pet. 40:218-227. https://doi.org/10.5398/ medpet.2017.40.3.218

Sinaga, B.M. 2011. Pendekatan Kuantitatif dalam Penelitian Agribisnis: Konsep, Model dan Metode. Program Studi Ilmu Ekonomi Pertanian. Sekolah Pascasarjana. Institut Pertanian Bogor, Bogor.

Sirajuddin, S. N., H. Siregar, B. Juanda, \& A. H. Dharmawan. 2012. The influences of transaction costs on dairy 
farming system in South Sulawesi Province. Jurnal Ilmu dan Teknologi Peternakan 1: 17-26.

Sitepu, R.K. \& B.M. Sinaga. 2018. Aplikasi Model Ekonometrika: Estimasi, Simulasi dan Peramalan Menggunakan Program SAS ${ }^{\circledR}$ 9.2. PT Penerbit IPB Press, Bogor.

Srairi, M.T., M.E. Jaouhari, A. Saydi, M.Kuper, \& Y.L. Gal. 2010. Supporting small-scale dairy farmers in increasing milk production:evidence from Morocco. Trop. Anim. Health Prod. 43:41-49. https://doi.org/10.1007/s11250-010-9652-9

Wantasen, E \& U. Paputungan. 2017. Household income investigation in smallholder cattle farming at Minahasa Regency North Sulawesi Province-Indonesia. Journal of
Agriculture and Veterinary Science 10:06-12. https://doi. org/10.9790/2380-1007020612

Widiasti, W., T. Prasetyo, Y.Y. Suranin, S. Nistini, Supriadi, \& I. Harsanto. 2010. The performance of credit program for smallholder's dairy cattle development in Indonesia. The $5^{\text {th }}$ International Seminar on Tropical Animal Production. Community Empowerment and Tropical Animal Industry. October 19-22, 2010. Yogyakarta, Indonesia.

Yuliandri, L.A. 2015. Pola dan perilaku konsumsi pangan asal ternak pada rumah tangga peternak sapi perah di Jawa Tengah. Jurnal Ilmu Pertanian dan Peternakan 3:1-10. 